\title{
One-pot synthesis of small spirocarbocycles through the catalytic cyclometalation reactions of unsaturated compounds
}

\author{
Vladimir A. D’yakonov, * Regina A. Tuktarova, Olga A. Trapeznikova, Leonard M. \\ Khalilov, and Natal'ya R. Popod'ko \\ Institute of Petrochemistry and Catalysis, Russian Academy of Sciences, \\ 141 Prospekt Oktyabrya, Ufa 450075, Russia \\ E-mail:DyakonovVA@rambler.ru
}

Dedicated to Professor Usein M. Dzhemilev on the occasion of his $65^{\text {th }}$ birthday

\begin{abstract}
The mild and efficient one-pot methods to synthesize substituted spirocyclopropanes and spirocyclobutanes are reported. The elaborated procedures based on consecutive cycloalumination of methylenecyclopropanes, methylenecyclobutanes or cycloalkynes assisted by alkyl aluminums and $\mathrm{Cp}_{2} \mathrm{ZrCl}_{2}$ as a catalyst provide the formation of target products through Pd catalyzed carbocyclization of the aluminacyclopentane and aluminacyclopentene intermediates with $\mathrm{Me}_{2} \mathrm{SO}_{4}$ or allyl chloride.
\end{abstract}

Keywords: Cyclometallation, cyclopropanation, homogeneous catalysis, spiranes, cyclopropane, cyclobutane, Dzhemilev reaction

\section{Introduction}

Small carbocycles are of special interest due to a variety of rearrangements into isomeric unsaturated compounds that have defined their wide use as building blocks for the directed synthesis of strained cyclic organic systems. In addition, among those containing three- and fourmembered carbocycles, one can often meet medical and biological preparations, plant protection products, and energy-rich components for jet fuel.

Ordinary approaches to small carbocycles are based on the classical procedures ${ }^{1}$ such as $1, \omega-$ elimination, Favorskii rearrangement, Dieckmann, Perkin and Simmons-Smith reactions, cyclopropanation of unsaturated hydrocarbons with diazocompounds as well as through concerted cycloaddition and cyclization reactions and also new ones, e.g. nontrivial transformations of acetylenes to mono- and biscyclopropanes mediated by aluminum carbenoids. $^{2}$ 
Of real interest are the methods, elaborated in the last 10-15 years, for the construction of cyclopropane alcohols ${ }^{3}$ and ethers ${ }^{4}$ by the interaction between esters and Grignard reagents or alkylhalogenalanes in the presence of $\mathrm{Ti}$ and $\mathrm{Zr}$ complexes through the three-membered metallacarbocycles.

To a number of promising procedures in the synthesis of small carbocycles, in our opinion, it should be also added those including intramolecular transformations of the five-membered nontransition metallacarbocycles such as aluminacyclopentanes ${ }^{5}$, aluminacyclopentenes, ${ }^{6}$ magnesacyclopentanes ${ }^{7}$ and their derivatives in situ generated in the cycloalumination and cyclomagnesiation reactions of unsaturated compounds with alkyl aluminums or alkyl magnesiums under the effect of Ti and $\mathrm{Zr}$ catalysts (Dzhemilev reaction). ${ }^{8}$

As known, ${ }^{6 \mathrm{~d}, 9}$ the interaction between 2,3-dialkylsubstituted aluminacyclopent-2-enes $\mathbf{1}$ and dimethyl sulphate or bromomethyl methyl ether as well as carbocyclization of 3alkylaluminacyclopentanes 2 with allyl chloride in the presence of $\mathrm{Ni}(\mathrm{acac})_{2}$ provides the formation of cyclopropanes 3-5. At the same time, the Pd catalyzed intramolecular cyclization of monoalkyl and dialkyl substituted aluminacyclopentanes represents an effective method for the construction of cyclobutanes 6 (Scheme 1). ${ }^{10}$

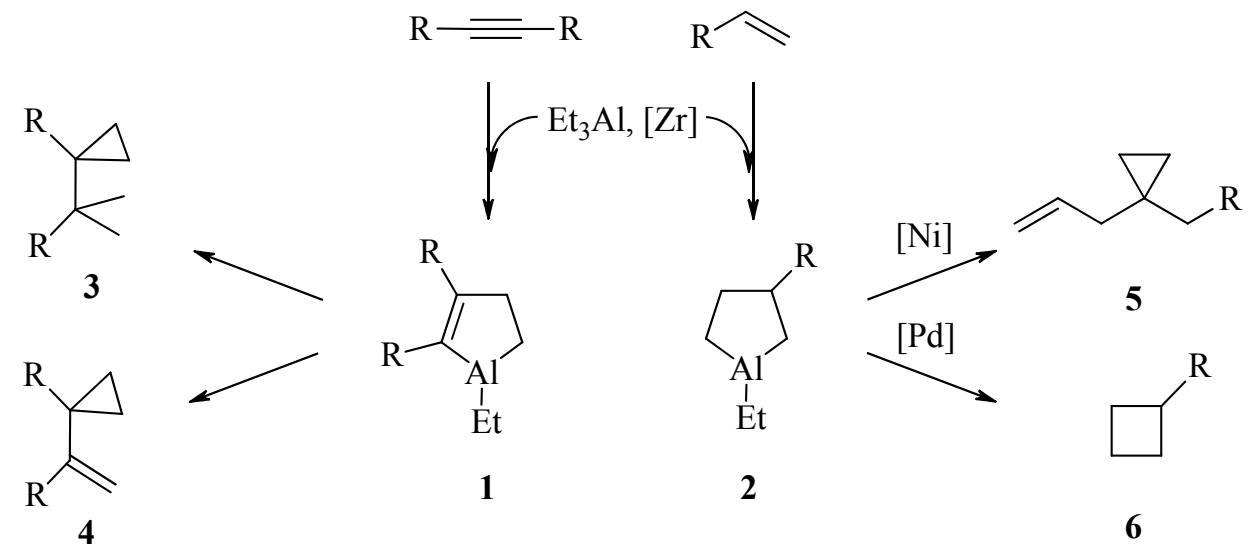

\section{Scheme 1}

As described above, the aluminum-based transformations of the five-membered metallacarbocycles have been studied on the example of the simplest alkyl substituted aluminacyclopentanes and aluminacyclopent-2-enes. Meanwhile, the investigation of such transformations with the aid of more complicated organoaluminum and organomagnesium compounds is thought to initiate the development of novel one-pot procedures for the synthesis of polycycles containing spirocyclopropane and spirocyclobutane moieties.

In this paper, we report new approaches to small spirocycles via intramolecular carbocyclization of di-, tri- and polycyclic aluminacyclopentanes and aluminacyclopentenes from methylenecycloalkanes, cycloalkynes, cycloalkadiines and cyclic allenes using the Dzhemilev method. 


\section{Results and Discussion}

Recently, ${ }^{11}$ we have synthesized the first representative of a new class of cyclic organoaluminum compounds (OACs) of a spirane structure, namely 6-ethyl-6-aluminaspiro[3.4]octane 7, via the interaction between methylenecyclobutane and $\mathrm{Et}_{3} \mathrm{Al}$ in the presence of $5 \mathrm{~mol} \% \mathrm{Cp}_{2} \mathrm{ZrCl}_{2}$ (pentane, $4 \mathrm{~h}$ ). It was found that the $\mathrm{OAC} \mathrm{7,} \mathrm{without} \mathrm{preliminary} \mathrm{isolation,} \mathrm{can} \mathrm{enter} \mathrm{into} \mathrm{reaction}$ with allyl chloride easily converted into spiro[3.3]heptane 8 (90\%) in the presence of $2 \mathrm{~mol} \%$ $\operatorname{Pd}(\operatorname{acac})_{2}$ (Scheme 2).

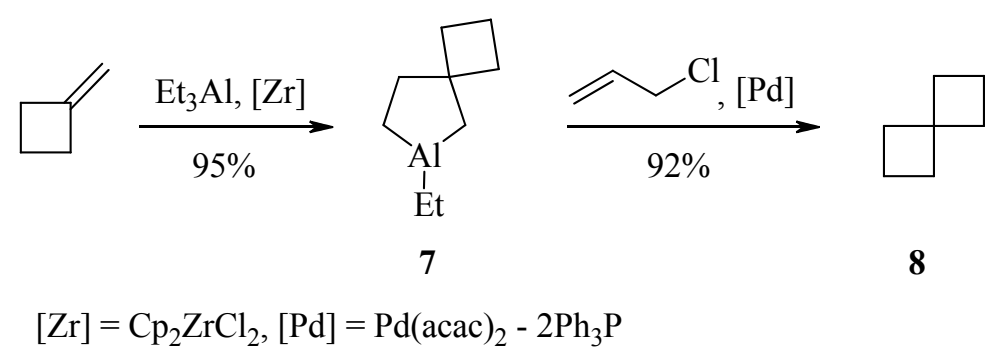

\section{Scheme 2}

This reaction is general and can be successfully used in the synthesis of 2-akyl substituted spiro[3.3]heptanes. Thus, the consecutive cycloalumination of 3-pentyl(heptyl) methylenecyclobutanes with $\mathrm{Et}_{3} \mathrm{Al}$ catalyzed by $\mathrm{Cp}_{2} \mathrm{ZrCl}_{2}$ under previously optimized conditions (methylenecyclobutane:Et ${ }_{3} \mathrm{Al}:[\mathrm{Zr}]=10: 12: 0.5,4$ h, r.t., hexane) ${ }^{11}$ affords appropriate 2-pentyl-, 2-heptylspiro[3.3] heptanes 10a,b (82-89\%) through the generated in situ spiranes 9a,b and their further carbocyclization mediated by allyl chloride and Pd catalyst (Scheme 3 ).

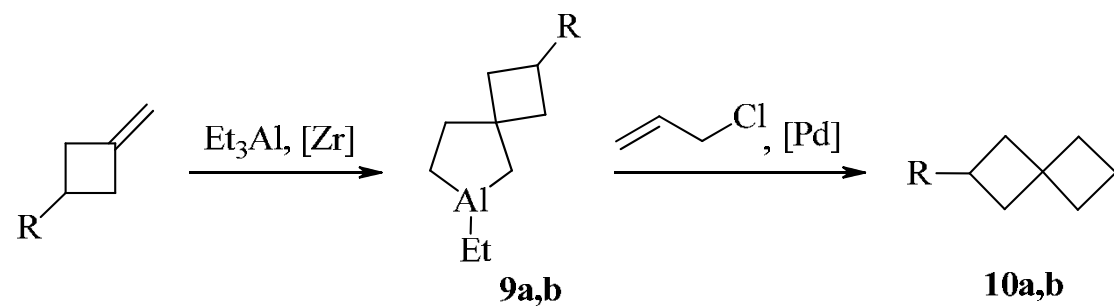

$$
[\mathrm{Zr}]=\mathrm{Cp}_{2} \mathrm{ZrCl}_{2} ; \mathrm{a}=\mathrm{n}-\mathrm{C}_{5} \mathrm{H}_{11}, \mathrm{~b}=\mathrm{n}-\mathrm{C}_{7} \mathrm{H}_{15}
$$

\section{Scheme 3}

In continuation of these studies and also in order to synthesize polycyclic hydrocarbons of spirane structure, we have studied, for the first time, catalytic transformations of aluminaspiro[3.4] octanes $\mathbf{1 5}-\mathbf{1 8}^{12}$ as intermediates in cycloalumination of 3-methylene-exotricyclo[4.2.1.0 $\left.0^{2,5}\right]$ nonane $\quad \mathbf{1 1}, \quad 3$-methylene-7-pentyl-exo-tricyclo[4.2.1.0 2,5$]$ nonane $\quad \mathbf{1 2}, \quad 3$ - 
methylene-exo-pentacyclo[5.4.0.0 $\left.0^{2,5} \cdot 0^{6,10} \cdot 0^{9,11}\right]$ undecane 13 and also 3,9-dimethylene-exo-exotetracyclo[4.4.1. $\left.0^{2,5} \cdot 0^{7,10}\right]$ undecane 14. These spiranes, as we have previously shown, easily reacts in situ with an excess of allyl chloride to give the corresponding spiro[3.3]heptanes retaining norbornane skeleton of parent compounds 19-22.

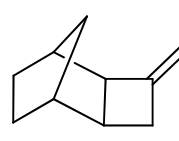

11
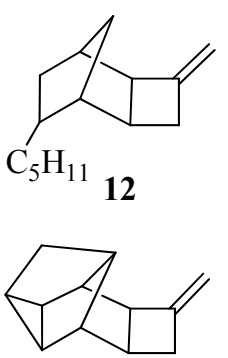

13

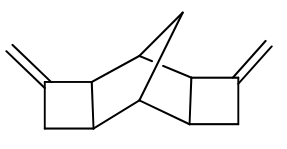

14
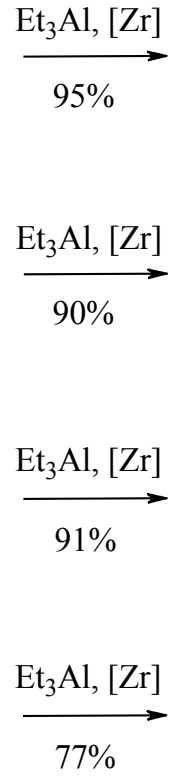

$77 \%$

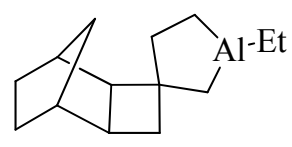

15
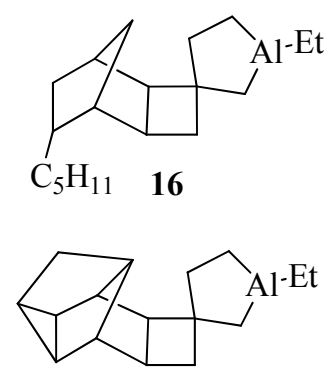

17

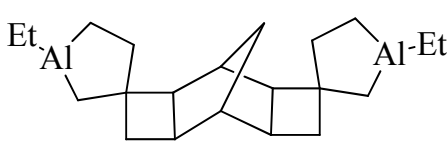

18
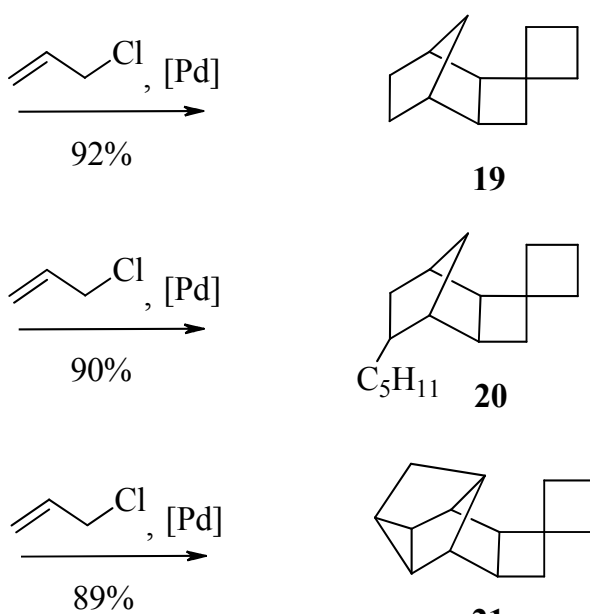

19
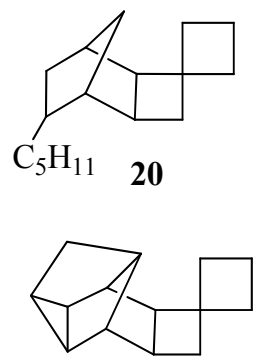

21
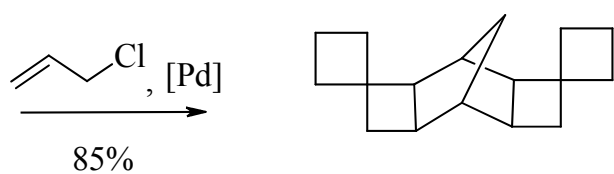

22

\section{Scheme 4}

Very encouraging results, obtained in the course of developing one-pot methods to synthesize spiro[3.3] heptanes by the intramolecular carbocyclization reaction of 6-ethyl-6aluminaspiro[3.4]octanes, prompted us to apply the same approach to the construction of spiro[2.3]hexane systems.

Initially, we investigated the activities of 2-pentyl- and 2-phenylmethylenecyclopropanes, as selected samples, in the reaction of catalytic cycloalumination with $\mathrm{Et}_{3} \mathrm{Al}$ and also their ability to give substituted aluminaspiro[2.4]heptanes.

The interaction between $\mathrm{Et}_{3} \mathrm{Al}$ and 2-pentyl-1-methylenecyclopropanes in the presence of 5 mol\% $\mathrm{Cp}_{2} \mathrm{ZrCl}_{2}$ (hexane, $4 \mathrm{~h}$ ) was found to afford a mixture of two theoretically possible regioisomeric aluminacyclopentanes 24 and 25 (81\% total) bearing cyclopropane ring in $\alpha$ - and $\beta$-position towards to $\mathrm{Al}$ atom respectively. Deuterolysis of this regioisomeric mixture led to hydrocarbons 26 and 27 at a 2:1 ratio. The Pd catalyzed reaction with allyl chloride provided the formation of spirocyclobutane $\mathbf{2 8}$ in $\mathbf{7 3 \%}$ yield (Scheme 5). 


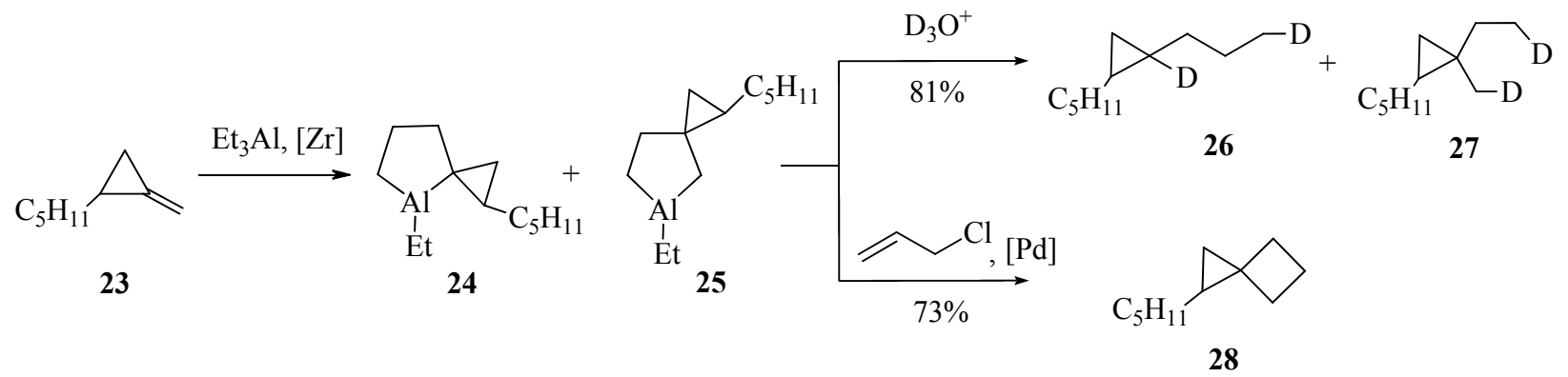

\section{Scheme 5}

We revealed that the nature of a substituent in the methylenecyclopropane ring determines the selectivity of the reaction. Thus, under previously developed conditions, 2phenylmethylenecyclopropane entered into reaction with $\mathrm{Et}_{3} \mathrm{Al}$ furnishing 4-ethyl-1-phenyl-4 aluminaspiro[2.4]heptane $\mathbf{3 0}$ with high regioselectivity (Scheme 6).

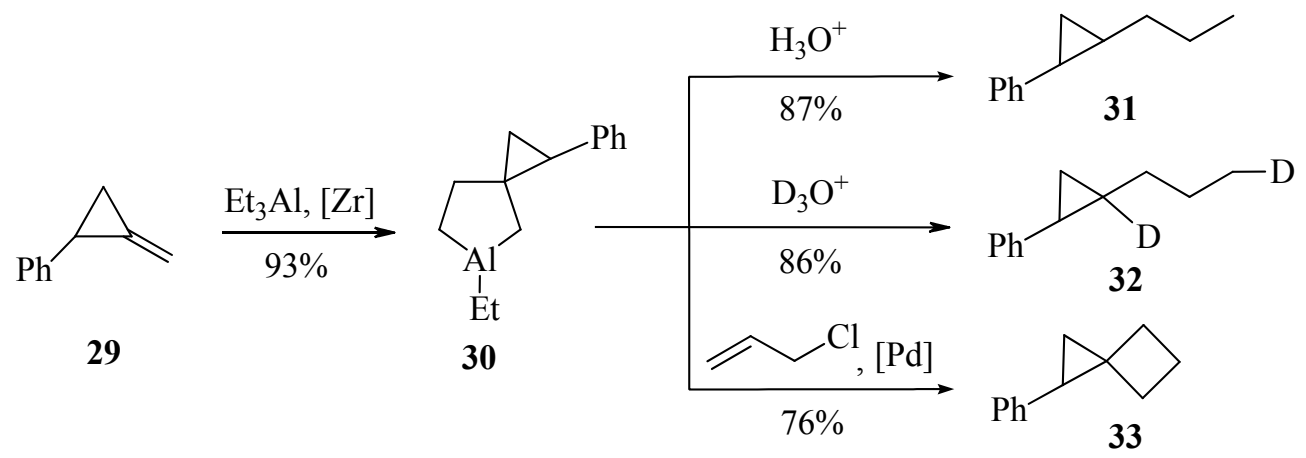

\section{Scheme 6}

The structure of the new OACs $\mathbf{2 4 ,} \mathbf{2 5}$ and $\mathbf{3 0}$ has been proven through analysis of the onedimensional $\left({ }^{1} \mathrm{H},{ }^{13} \mathrm{C}, \mathrm{APT}\right)$ and two-dimensional (HH COSY, HSQC and HMBC) NMR spectra of the acid hydrolysis $\mathbf{3 1}$ and deuterolysis products 26, 27, and $\mathbf{3 2}$.

Thus, the ${ }^{1} \mathrm{H}$ and ${ }^{13} \mathrm{C}$ NMR spectra of the hydrocarbon 31 show the low field signals corresponding to the aromatic protons and carbons of the phenyl ring, while the alkyl substituent and cyclopropane moiety manifest themselves in the high field of the spectra. The methylene protons at the $\alpha$-carbon $[\delta(\mathrm{C}-10) 30.7 \mathrm{ppm}]$ attributable to the alkenyl substituent are observed as two multiplets $[\delta \mathrm{H}(\mathrm{C}-10) 0.91$ and $1.18 \mathrm{ppm}]$ due to diastereotopic splitting at the chiral $\mathrm{C}-2$ center. 1,2-Disubstituted cyclopropane fragment is represented by a four spin systems associated with two methine $[\delta \mathrm{H}(\mathrm{C}-1) 2.13$ and $\delta(\mathrm{H}-2) 1.13 \mathrm{ppm}]$ and also two methylene protons $[\delta \mathrm{H}(\mathrm{C}-$ 3) 0.67 and $0.99 \mathrm{ppm}]$.

Assignment of cis and trans isomers has been performed on the basis of vicinal coupling constants (SSCC). Thus, in the ${ }^{1} \mathrm{H}$ NMR spectrum of trans-isomer, theoretically, the signal resonated in a low field $[\delta \mathrm{H}(\mathrm{C}-1) 2.13 \mathrm{ppm}]$ must comply with one large $\left({ }^{3} J_{\text {cis }} \approx 8-10 \mathrm{~Hz}\right)$ and two average $\left({ }^{3} J_{\text {trans }} \approx 4-6 \mathrm{~Hz}\right)$ coupling constants. 
In the experimental spectrum, there are two large vicinal $\left({ }^{3} J_{\text {cis }}=8 \mathrm{~Hz}\right)$ and one average $\left({ }^{3} J_{\text {trans }}\right.$ $=5 \mathrm{~Hz}$ ) coupling constants corresponding to the signal at $\delta 2.13 \mathrm{ppm}$. These data clear indicate cis-arrangement of phenyl and propyl substituents with respect to the cyclopropane ring.

Location of deuteriums in compound $\mathbf{3 2}$ obtained from deuterolysis of OAC $\mathbf{3 0}$ is determined by the splitting of signals assigned to the methyl C-3 and C-6 carbons ( $\delta 18.9$ and $14.0 \mathrm{ppm}$ ) with a shift of a triplet centre towards the high field $\left(\Delta \delta_{C} 0.3 \mathrm{ppm}\right)$. These data and also the SSCC magnitude $\left({ }^{1} J_{\mathrm{CD}}=19 \mathrm{~Hz}\right)$ are the additional arguments for the formation of a cyclic OAC 30.

To achieve the stated goals, generated in situ aluminaspiro[2.4] heptanes 24, 25 and $\mathbf{3 0}$ under previously developed conditions were subjected to carbocyclization. As a result, 1-pentyl 28 and 1-phenylspiro[2.3] hexane 33 have been obtained in high yields (Scheme 5, 6).

We believe that the above reactions have considerable synthetic potential and their further studies will lead in future to the development of a general method to synthesize spiro[2.3]hexanes, spiro[2.3]heptanes and spiro[4.3]octanes, including those containing functional substituents.

In the development of the other approach to small carbocycles, based on intramolecular carboalumination of 2,3-dialkylaluminacyclopent-2-ene, with the aid of dimethyl sulfate ${ }^{9}$ or bromomethyl methyl ether ${ }^{6 \mathbf{d}}$, for the first time the catalytic cycloalumination reaction of cycloalkynes has been performed (Scheme 1).

Thus, we revealed that cycloalkynes, for example, cyclododecyne or cyclotridecyne react with $\mathrm{Et}_{3} \mathrm{Al}$ in the presence of catalytic amounts of $\mathrm{Cp}_{2} \mathrm{ZrCl}_{2}(5 \mathrm{~mol} \%)$ in aliphatic (pentane, hexane, heptane) or aromatic (benzene, toluene) solvents to afford not previously described bicyclic aluminacyclopentanes $\mathbf{3 5 a}, \mathbf{b}$ in $78-89 \%$ yield.

Subsequent treatment of in situ generated OAC 35a with an excess $\mathrm{Me}_{2} \mathrm{SO}_{4}$ or equimolar amounts of bromomethyl methyl ether at $0{ }^{\circ} \mathrm{C}$ furnished 4,4-dimethylspiro[2.7]decane 36a and 4-methylenespiro[2.7]decane $37 \mathbf{a}$ in the yield of $84 \%$ and $91 \%$ respectively. Using the $\mathrm{Et}_{3} \mathrm{Al}-$ $\mathrm{CH}_{2} \mathrm{I}_{2}$ reagent through the cyclopropanation reaction the latter was converted into dispiro[2.0.2.6]dodecane 38a (Scheme 7).

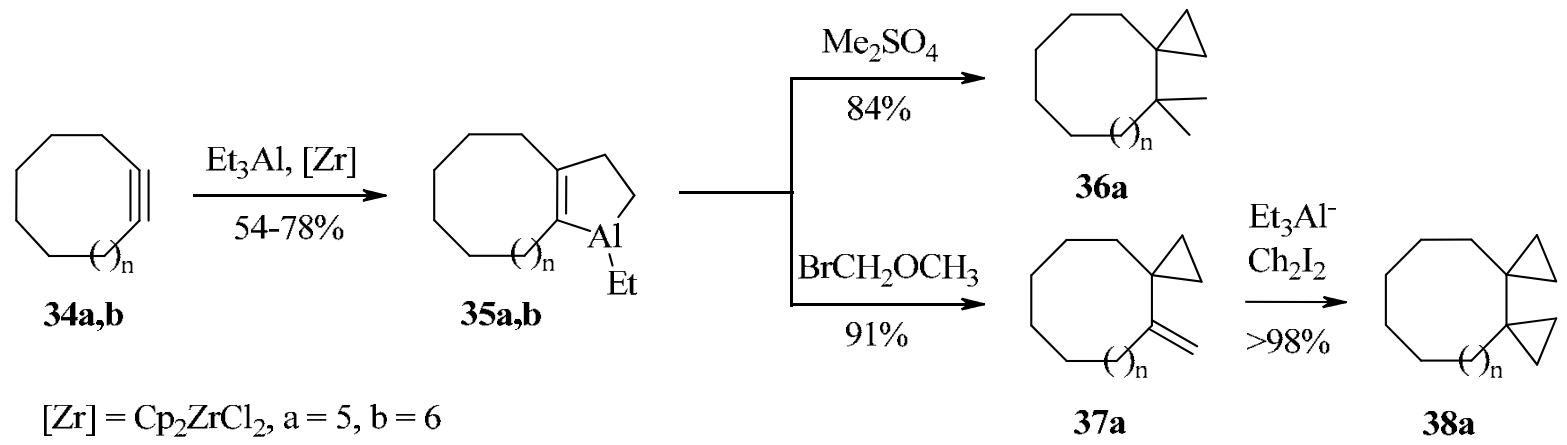

\section{Scheme 7}


Taking into account the experimental data obtained from catalytic cycloalumination of disubstituted acetylenes $^{6 \mathrm{c}, \mathrm{d}}$ on the example of cyclotetradeca-1,8-diyne 39, we elaborated reaction conditions (cycloalkadiyne: $\mathrm{Et}_{3} \mathrm{Al}:[\mathrm{Zr}]=1: 6: 0.1$, hexane, $20-22{ }^{\circ} \mathrm{C}, 6 \mathrm{~h}$ ), under which the pointed cycloalkadiyne entered into the cycloalumination reaction with $\mathrm{Et}_{3} \mathrm{Al}$ in the presence of $10 \mathrm{~mol} \% \quad \mathrm{Cp}_{2} \mathrm{ZrCl}_{2}$ involving two triple bonds to form isomeric tricyclic bisaluminacyclopentenes $\mathbf{4 0 a}$ and $\mathbf{4 0 b}$ in a $1: 1$ ratio (Scheme 8).

Carbocyclization of OAC $\mathbf{4 0}$ aided by equimolar amount of bromomethyl methyl ether gave rise to 12,18-dimethylenedispiro[2.5.2.7] octadecane 41a and 4,13-dimethylenedispiro[2.6.2.6] octadecane $41 \mathrm{~b}$ in $88 \%$ overall yield. Treatment of a mixture of regioisomeric dimethylenedispiro(cyclopropane)octadecanes with the cyclopropanation reagent $\mathrm{Et}_{3} \mathrm{Al}-\mathrm{CH}_{2} \mathrm{I}_{2}$ quantitatively led to tetraspiro[2.0.2 $\left.2^{4} \cdot 5 \cdot 2^{12} \cdot 0 \cdot 2^{15} \cdot 5^{3}\right]$ docosane 42 .

The structure of all compounds synthesized has been rigorously proven by means of onedimensional $\left({ }^{1} \mathrm{H},{ }^{13} \mathrm{C}\right.$, Dept $\left.135^{\circ}\right)$ and two-dimensional (HSQC, HMBC, HH COSY, NOESY) NMR spectroscopic data.

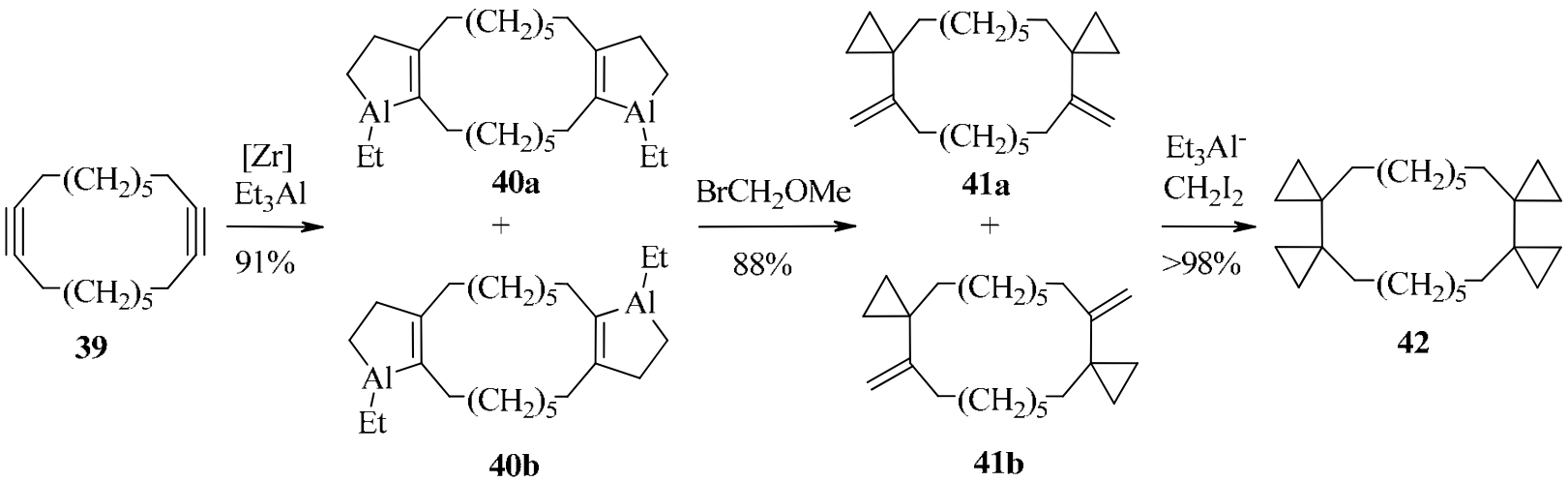

\section{Scheme 8}

For comparison, we presented perhaps the single example of intramolecular cyclization of five-membered magnesacarbocycle successfully obtained from cyclonona-1,2-diene through the catalytic cyclomagnesiation reaction.

Previously, ${ }^{13}$ we have shown that selective interaction between cyclic allenes and Grignard reagents mediated by metallic $\mathrm{Mg}$ and $\mathrm{Cp}_{2} \mathrm{TiCl}_{2}$ catalyst affords tricyclic magnesacyclopentadienes in the yields more than $90 \%$. According to the published results on the transformation of the substituted aluminacyclopentanes to the corresponding cyclobutanes in the presence of $\mathrm{CuCl}_{2}$ we have implemented intramolecular carbocyclization of magnesacyclopentane 43 to $(10 R, 11 S)$-tricyclo[9.7.0 $0^{1,11} \cdot 0^{2,10}$ ]octadeca-2(3), 18-diene 44 in $68 \%$ yield (Scheme 9). 

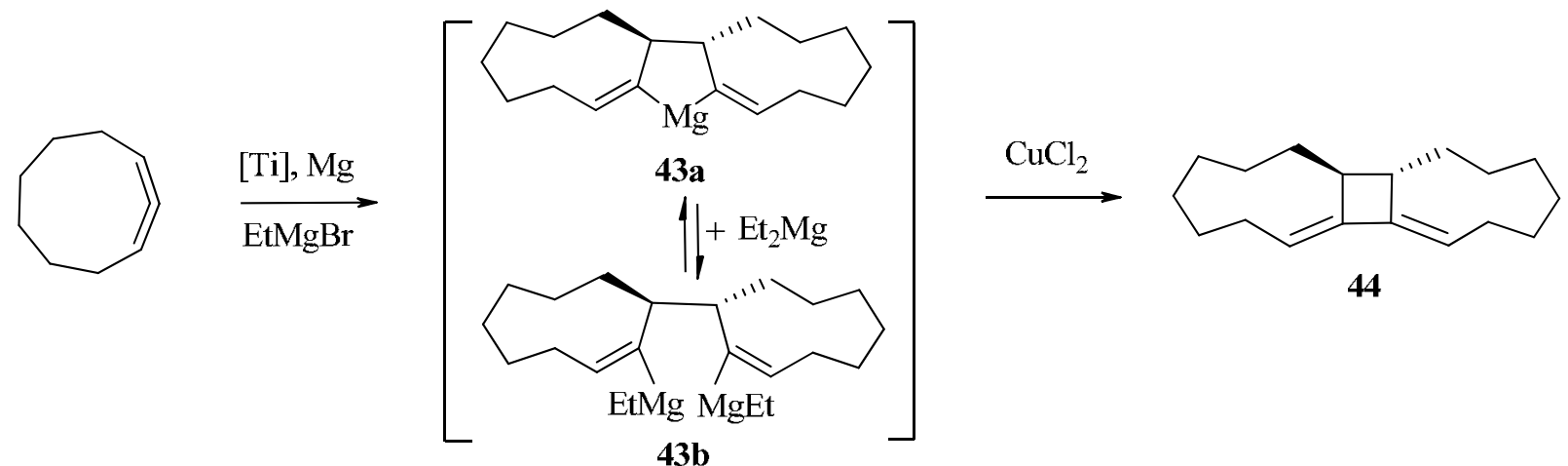

\section{Scheme 9}

Our proposed approach compares favorably with previously elaborated methods for the synthesis of tricyclic diene 44 , since thermal or catalytic $2 \pi+2 \pi$-cyclodimerization of 1 ,2cycononadiene resulted in a mixture of three stereoisomers, in which the maximum content of 44 does not exceed $63 \%{ }^{14}$

In addition, using our methodology one can synthesize diastereomeric pure $(10 R, 11 S)$ tricyclo[9.7.0 $\left.0^{1,11} \cdot 0^{2,10}\right]$ octadeca-2(3),18-diene 44 .

\section{Conclusions}

Thereby, the five-membered organoaluminum and organomagnesium compounds obtained by the Dzhemilev reaction have proven to be promising synthons while designing efficient one-pot procedures to obtain various spirocyclopropanes and spirocyclobutanes from accessible methylenecycloalkanes, cyclic 1,2-dienes and acetylenes.

\section{Experimental Section}

General. All solvents were dried (hexane over $\mathrm{LiAlH}_{4}, \mathrm{Et}_{2} \mathrm{O}$ and $\mathrm{THF}$ over $\mathrm{Na}$ ) and freshly distilled before use. All reactions were carried out under a dry argon atmosphere. The reaction products were analyzed using chromatography on a "Shimadzu GC-9A" instrument (2000 x 2 mm column packed with 5\% of SE-30 and 15\% PEG-6000 on Chromaton N-AW, carrier gas $\mathrm{He}$ ). The IR-spectra were recorded on "Bruker VERTEX 70V". Mass spectral measurements were performed on a Finnigan-4021 spectrometer at $70 \mathrm{eV}$ and working temperature $200{ }^{\circ} \mathrm{C}$. Elemental analysis of samples was determined on Carlo Erba, model 1106. The ${ }^{1} \mathrm{H}$ and ${ }^{13} \mathrm{C}$ NMR spectra were recorded as $\mathrm{CDCl}_{3}$ solutions on spectrometer "Bruker Avance-400" (100 MHz for ${ }^{13} \mathrm{C}$ and $400 \mathrm{MHz}$ for ${ }^{1} \mathrm{H}$ ). The chemical shifts are reported as $\delta$ values in ppm relative to internal standard $\mathrm{Me}_{4} \mathrm{Si} .{ }^{13} \mathrm{C}$ NMR spectra were edited by $J$-modulation (JMOD) on $\mathrm{CH}$ constants. The 
yields of organoaluminum compounds $9 \mathbf{a}, \mathbf{b}, \mathbf{2 4}, \mathbf{2 5}, \mathbf{3 0}, \mathbf{3 5 a}, \mathbf{b}, \mathbf{4 0}, \mathbf{a}, \mathbf{b}$ were determined by GLC analysis of the corresponding deuterium or hydrolysis derivatives. Compound $\mathbf{3 3}$ was identified by comparing their physical properties and spectral parameters with those of authentic sample. ${ }^{15}$

Synthesis of spiro[2.3]hexanes and spiro[3.3]heptanes. General procedure Methylidenecyclopropane (methylidenecyclobutane) $(10 \mathrm{mmol}), \mathrm{Cp}_{2} \mathrm{ZrCl}_{2}(0.5 \mathrm{mmol})$, hexane $(15 \mathrm{~mL})$, and $\mathrm{Et}_{3} \mathrm{Al}(12 \mathrm{mmol})$ were placed into a glass reactor under dry argon at $0{ }^{\circ} \mathrm{C}$ with stirring. The temperature was elevated to ambient $\left(20-21{ }^{\circ} \mathrm{C}\right)$ and the reaction mixture was stirred for $4 \mathrm{~h}$, then, $\mathrm{Et}_{2} \mathrm{O}(10 \mathrm{~mL}), \mathrm{Ph}_{3} \mathrm{P}(0.5 \mathrm{mmol}), \mathrm{Pd}(\mathrm{acac})_{2}(0.5 \mathrm{mmol})$, and allyl chloride (30 mmol) were added at $0{ }^{\circ} \mathrm{C}$, the temperature was raised to ambient and the stirring was continued for $8 \mathrm{~h}$. The reaction mixture was worked up with $7-10 \%$ aq. $\mathrm{HCl}$, the reaction products were extracted with diethyl ether, dried with $\mathrm{MgSO}_{4}$ and isolated by distillation in vacuo.

2-Pentylspiro[3.3]heptane (10a). IR (film) v 3050, 2995, 1715, 1460, $1151 \mathrm{~cm}^{-1}$; ${ }^{1} \mathrm{H}$ NMR $\left(\mathrm{CDCl}_{3}, 400 \mathrm{MHz}\right) \delta 2.07-2.10(\mathrm{~m}, 3 \mathrm{H}), 1.97(\mathrm{t}, J=7.1 \mathrm{~Hz}, 2 \mathrm{H}), 1.82-1.84(\mathrm{~m}, 2 \mathrm{H}), 1.79-1.83$ (m, 2H), 1.50-1.53 (m, 2H), 1.15-1.38 (m, 8H), $0.93(\mathrm{t}, J=6.5 \mathrm{~Hz}, 3 \mathrm{H}) ;{ }^{13} \mathrm{C} \mathrm{NMR}\left(\mathrm{CDCl}_{3}, 100\right.$ MHz) $\delta 41.0,39.8,37.4,35.6,35.2,31.7,28.6,22.7,16.7,14.0$; MS (ES) $\mathrm{m} / \mathrm{z}[\mathrm{M}]^{+}$166. Anal. Calcd. for $\mathrm{C}_{12} \mathrm{H}_{22}$ : C, 86.67; $\mathrm{H}, 13.33$. Found: $\mathrm{C}, 86.49 ; \mathrm{H}, 13.31$.

2-Heptylspiro[3.3]heptane (10b). IR (film) v 3045, 2999, 1705, 1456, $1154 \mathrm{~cm}^{-1}$; ${ }^{1} \mathrm{H}$ NMR $\left(\mathrm{CDCl}_{3}, 400 \mathrm{MHz}\right) \delta 2.06-2.09(\mathrm{~m}, 3 \mathrm{H}), 1.99(\mathrm{t}, J=6.8 \mathrm{~Hz}, 2 \mathrm{H}), 1.86-1.88(\mathrm{~m}, 2 \mathrm{H}), 1.79-1.82$ $(\mathrm{m}, 2 \mathrm{H}), 1.51-1.53(\mathrm{~m}, 2 \mathrm{H}), 1.16-1.36(\mathrm{~m}, 12 \mathrm{H}), 0.9(\mathrm{t}, J=6.4 \mathrm{~Hz}, 3 \mathrm{H}) ;{ }^{13} \mathrm{C} \mathrm{NMR}\left(\mathrm{CDCl}_{3}, 100\right.$ MHz) $\delta 41.2,40.2,37.2,35.8,35.2,31.9,29.4,29.6,27.4,22.7,16.6,14.1$; MS (ES) $m / z[M]^{+}$ 194. Anal. Calcd. for $\mathrm{C}_{14} \mathrm{H}_{26}$ : C, 86.52; H, 13.48. Found: $\mathrm{C}, 86.39 ; \mathrm{H}, 13.49$.

Spiro[cyclobutane-1,3'-exo-tricyclo[4.2.1.0 ${ }^{2,5}$ ]nonane] (19). B.p. $77-78^{\circ} \mathrm{C}$ (3 Torr). IR (film) $v$ 1665, 1640, 995, 915, $890 \mathrm{~cm}^{-1}$; ${ }^{1} \mathrm{H}$ NMR $\left(\mathrm{CDCl}_{3}, 400 \mathrm{MHz}\right) \delta 2.09$ (br.s, $\left.1 \mathrm{H}\right), 1.91-1.93(\mathrm{~m}$, $1 \mathrm{H}), 1.88$ (br.s, $1 \mathrm{H}), 1.84-2.03(\mathrm{~m}, 4 \mathrm{H}), 1.64-1.72(\mathrm{~m}, 5 \mathrm{H}), 1.55-1.57(\mathrm{~m}, 2 \mathrm{H}), 1.39-1.41(\mathrm{~m}$, 2H), 0.96-0.98 (m, 2H); ${ }^{13} \mathrm{C} \mathrm{NMR}\left(\mathrm{CDCl}_{3}, 100 \mathrm{MHz}\right) \delta 52.2,42.5,38.9,38.5,38.4,37.1,36.5$, 33.0, 29.7, 28.5, 27.7, 16.5; MS (ES) $m / z[M]^{+}$162. Anal. Calcd. for $\mathrm{C}_{14} \mathrm{H}_{26}: \mathrm{C}, 88.82 ; \mathrm{H}, 11.18$. Found: C, 88.74; H, 11.19 .

7-Pentylspiro[cyclobutane-1,3'-exo-tricyclo[4.2.1.0 ${ }^{2,5}$ ]nonane] (20). B.p. $109-112{ }^{\circ} \mathrm{C}$ (1 Torr). IR (film) v 1665, 1640, 995, 920, $890 \mathrm{~cm}^{-1} ;{ }^{1} \mathrm{H}$ NMR $\left(\mathrm{CDCl}_{3}, 400 \mathrm{MHz}\right) \delta 1.84-2.04(\mathrm{~m}, 8 \mathrm{H})$, $1.72(\mathrm{~m}, 2 \mathrm{H}), 1.59(\mathrm{~m}, 2 \mathrm{H}), 1.53-1.56(\mathrm{~m}, 2 \mathrm{H}), 1.22-1.29(\mathrm{~m}, 11 \mathrm{H}), 0.91(\mathrm{t}, 3 \mathrm{H}, J=7 \mathrm{~Hz}) ;{ }^{13} \mathrm{C}$ NMR $\left(\mathrm{CDCl}_{3}, 100 \mathrm{MHz}\right) \delta 50.8,42.7,41.2,40.0,38.6,38.4,37.4,36.3,35.7,34.3,32.5,32.1$, 30.4, 28.5, 22.5, 16.2, 14.1; MS (ES) $\mathrm{m} / z$ [M] $]^{+}$232. Anal. Calcd. for $\mathrm{C}_{17} \mathrm{H}_{28}$ : C, 87.86; H, 12.14 . Found: C, 87.79; H, 12.12 .

Spiro[cyclobutane-1,3'-exo-pentacyclo[5.4.0.0 $\left.0^{2,5} \cdot 0^{6,10} \cdot 0^{9,11}\right]$ undecane (21). B.p. $94-96{ }^{\circ} \mathrm{C}(5$ Torr). IR (film) v 1680, 995, 905, $885 \mathrm{~cm}^{-1} ;{ }^{1} \mathrm{H} \mathrm{NMR}\left(\mathrm{CDCl}_{3}, 400 \mathrm{MHz}\right) \delta 2.46-2.51(\mathrm{~m}, 1 \mathrm{H})$, 2.17-2.19 (m, 1H), 2.10-2.12 (m, 1H), 1.93 (br.s, 1H), 1.84 (br.s, 1H), 1.81-2.04 (m, 4H), 1.66$1.72(\mathrm{~m}, 1 \mathrm{H}), 1.53-1.58(\mathrm{~m}, 5 \mathrm{H}), 1.23-1.25(\mathrm{~m}, 1 \mathrm{H}), 0.89-1.04(\mathrm{~m}, 2 \mathrm{H}) ;{ }^{13} \mathrm{C} \mathrm{NMR}\left(\mathrm{CDCl}_{3}, 100\right.$ 
MHz) $\delta 51.3,46.2,43.2,42.2,38.9,38.1,36.6,36.4,31.9,31.5,29.8,16.2,13.9,12.9 ;$ MS (ES) $\mathrm{m} / \mathrm{z}[\mathrm{M}]^{+}$186. Anal. Calcd. for $\mathrm{C}_{14} \mathrm{H}_{18}$ : C, 90.26; H, 9.74. Found: C, 90.09; H, 9.76.

Dispiro[cyclobutane-1,3'-exo-tetracyclo[4.4.1.0 $\left.{ }^{\mathbf{2 , 5}} .0^{\mathbf{7}, 10}\right]$ undecane-9',1'-cyclobutane] (22). IR (film) v 1660, 1655, 995, 920, $880 \mathrm{~cm}^{-1} ;{ }^{1} \mathrm{H}$ NMR $\left(\mathrm{CDCl}_{3}, 400 \mathrm{MHz}\right) \delta 1.98$ (br.s, $\left.1 \mathrm{H}\right), 1.91-1.94$ $(\mathrm{m}, 2 \mathrm{H}), 1.83$ (br.s, $1 \mathrm{H}), 1.84-2.03(\mathrm{~m}, 8 \mathrm{H}), 1.63-1.75(\mathrm{~m}, 8 \mathrm{H}), 1.55-1.57(\mathrm{~m}, 4 \mathrm{H}) ;{ }^{13} \mathrm{C}$ NMR $\left(\mathrm{CDCl}_{3}, 100 \mathrm{MHz}\right) \delta 51.2,41.3,38.9,38.5,38.4,38.3,35.9,34.9,29.9,16.6 ; \mathrm{MS}$ (ES) $\mathrm{m} / \mathrm{z}[\mathrm{M}]^{+}$ 228. Anal. Calcd. for $\mathrm{C}_{17} \mathrm{H}_{24}: \mathrm{C}, 89.41 ; \mathrm{H}, 10.59$. Found: C, 89.34; H, 10.57 .

2-Deutero-1-pentyl-2-(3-deuteropropyl)cyclopropane (26). IR (film) $v 2170$ (CD) cm ${ }^{-1} ;{ }^{1} \mathrm{H}$ NMR $\left(\mathrm{CDCl}_{3}, 400 \mathrm{MHz}\right) \delta 1.25-1.44(\mathrm{~m}, 10 \mathrm{H}), 1.09-1.15(\mathrm{~m}, 2 \mathrm{H}), 0.93(\mathrm{t}, J=7.0 \mathrm{~Hz}, 2 \mathrm{H})$, $0.90(\mathrm{t}, J=7.0 \mathrm{~Hz}, 3 \mathrm{H}), 0.64(\mathrm{~m}, 1 \mathrm{H}), 0.58(\mathrm{~m}, 2 \mathrm{H}) ;{ }^{13} \mathrm{C} \mathrm{NMR}\left(\mathrm{CDCl}_{3}, 100 \mathrm{MHz}\right) \delta 32.1,30.9$, $30.1,28.9,23.4,22.6,15.8,15.3\left(\mathrm{t}, J_{C D}=19.0 \mathrm{~Hz}\right), 14.0,13.8\left(\mathrm{t}, J_{C D}=19.0 \mathrm{~Hz}\right), 10.8$; MS (ES) $\mathrm{m} / \mathrm{z}[\mathrm{M}]^{+}$156. Anal. Calcd. for $\mathrm{C}_{11} \mathrm{H}_{20} \mathrm{D}_{2}$ : C, 84.53; H, 12.9; D, 2.57. Found: C, 84.34; H+D, 14.95 .

1-(2-Deuteroethyl)-1-deuteromethyl-2-pentylcyclopropane (cis:trans-1:1) (27). IR (film) $v$ $2160(\mathrm{CD}) \mathrm{cm}^{-1} ;{ }^{1} \mathrm{H} \mathrm{NMR}\left(\mathrm{CDCl}_{3}, 400 \mathrm{MHz}\right) \delta 1.18-1.44(\mathrm{~m}, 10 \mathrm{H}), 1.03(\mathrm{~s}, 2 \mathrm{H}), 0.97(\mathrm{t}, J=7.0$ $\mathrm{Hz}, 3 \mathrm{H}), 0.91(\mathrm{t}, J=7.0 \mathrm{~Hz}, 2 \mathrm{H}), 0.15-0.44(\mathrm{~m}, 3 \mathrm{H}) ;{ }^{13} \mathrm{C} \mathrm{NMR}\left(\mathrm{CDCl}_{3}, 100 \mathrm{MHz}\right) \delta 34.4(34.2)$, 32.6, 30.5, 28.6, 26.6, 22.6, $20.3(20.1)\left(\mathrm{t}, J_{C D}=19.0 \mathrm{~Hz}\right), 18.6(19.0), 14.2,10.8(10.7)\left(\mathrm{t}, J_{C D}=\right.$ $19.0 \mathrm{~Hz}$ ); MS (ES) $\mathrm{m} / \mathrm{z}[\mathrm{M}]^{+}$156. Anal. Calcd. for $\mathrm{C}_{11} \mathrm{H}_{20} \mathrm{D}_{2}$ : C, 84.53; H, 12.9; D, 2.57. Found: C, 84.44; H+D, 14.98 .

1-Pentylspiro[2.3]hexane (28). IR (film) $v$ 3069, 2995, 1705, 1460, 1160, $760 \mathrm{~cm}^{-1} ;{ }^{1} \mathrm{H} \mathrm{NMR}$ $\left(\mathrm{CDCl}_{3}, 400 \mathrm{MHz}\right) \delta 2.05-2.10(\mathrm{~m}, 4 \mathrm{H}), 1.92-1.96(\mathrm{~m}, 2 \mathrm{H}), 1.12-1.36(\mathrm{~m}, 8 \mathrm{H}), 0.91(\mathrm{t}, J=6.5$ $\mathrm{Hz}, 3 \mathrm{H}), 0.49-0.56(\mathrm{~m}, 3 \mathrm{H}) ;{ }^{13} \mathrm{C} \mathrm{NMR}\left(\mathrm{CDCl}_{3}, 100 \mathrm{MHz}\right) \delta 31.2,30.9,30.4,29.3,28.1,26.4$, 22.4, 22.1, 18.1, 17.4, 14.0; MS (ES) $m / z$ [M] $]^{+}$152. Anal. Calcd. for $\mathrm{C}_{11} \mathrm{H}_{20}$ : C, 88.76; H, 13.24. Found: C, 88.68; H, 13.25 .

1-Phenyl-2-propylcyclopropane (31). IR (film) v 3070, 3030, 2995, 1705, 1460, $\mathrm{cm}^{-1}$; ${ }^{1} \mathrm{H}$ NMR $\left(\mathrm{CDCl}_{3}, 400 \mathrm{MHz}\right) \delta 7.28-7.30(\mathrm{~m}, 2 \mathrm{H}), 7.21-7.23(\mathrm{~m}, 2 \mathrm{H}), 7.18-7.19(\mathrm{~m}, 1 \mathrm{H}), 2.12-2.14(\mathrm{~m}$, $1 \mathrm{H}), 1.31-1.33(\mathrm{~m}, 2 \mathrm{H}), 1.18-1.19(\mathrm{~m}, 1 \mathrm{H}), 1.12-1.14(\mathrm{~m}, 1 \mathrm{H}), 0.98-0.99(\mathrm{~m}, 1 \mathrm{H}), 0.90-0.91(\mathrm{~m}$, $1 \mathrm{H}), 0.83(\mathrm{t}, J=7.0 \mathrm{~Hz}, 3 \mathrm{H}), 0.66-0.68(\mathrm{~m}, 1 \mathrm{H}) ;{ }^{13} \mathrm{C} \mathrm{NMR}\left(\mathrm{CDCl}_{3}, 100 \mathrm{MHz}\right) \delta 139.8,129.0$, 127.8, 125.8, 30.7, 22.5, 20.9, 18.8, 14.0, 9.6; MS (ES) m/z [M] $]^{+}$160. Anal. Calcd. for $\mathrm{C}_{12} \mathrm{H}_{16}$ : C, 89.94; H, 10.06. Found: C, 89.81; H, 10.04.

2-Deutero-1-phenyl-2-(3-deuteropropyl)cyclopropane (32). IR (film) $v 2160$ (CD) $\mathrm{cm}^{-1} ;{ }^{1} \mathrm{H}$ NMR $\left(\mathrm{CDCl}_{3}, 400 \mathrm{MHz}\right) \delta 7.17-7.31(\mathrm{~m}, 5 \mathrm{H}, \mathrm{Ph}), 2.12-2.14(\mathrm{~m}, 1 \mathrm{H}), 1.32-1.33(\mathrm{~m}, 2 \mathrm{H}), 1.19$ $1.20(\mathrm{~m}, 1 \mathrm{H}), 0.97-0.99(\mathrm{~m}, 1 \mathrm{H}), 0.92-0.94(\mathrm{~m}, 1 \mathrm{H}), 0.82(\mathrm{t}, J=7.0 \mathrm{~Hz}, 2 \mathrm{H}), 0.65-0.67(\mathrm{~m}, 1 \mathrm{H})$;

${ }^{13} \mathrm{C} \mathrm{NMR}\left(\mathrm{CDCl}_{3}, 100 \mathrm{MHz}\right) \delta 32.1,30.9,30.1,28.9,23.4,22.6,15.8,15.3\left(\mathrm{t}, J_{C D}=19.0 \mathrm{~Hz}\right)$, 14.0, $13.8\left(\mathrm{t}, J_{C D}=19.0 \mathrm{~Hz}\right), 10.8$; MS (ES) $\mathrm{m} / \mathrm{z}[\mathrm{M}]^{+}$162. Anal. Calcd. for $\mathrm{C}_{12} \mathrm{H}_{14} \mathrm{D}_{2}: \mathrm{C}, 88.83$; H, 8.70; D, 2.47. Found: C, 88.75; H+D, 11.23.

\section{Synthesis of 4,4-dimethylspiro[2.7]decane (36a)}

Cyclic alkyne $(5 \mathrm{mmol}), \mathrm{Cp}_{2} \mathrm{ZrCl}_{2}(0.25 \mathrm{mmol})$, hexane $(10 \mathrm{~mL})$, and $\mathrm{Et}_{3} \mathrm{Al}(15 \mathrm{mmol})$ were placed into a glass reactor under dry argon at $0{ }^{\circ} \mathrm{C}$ with stirring. The temperature was elevated to 
ambient $\left(20-21{ }^{\circ} \mathrm{C}\right)$ and the reaction mixture was stirred for $6 \mathrm{~h}$, then, $\mathrm{Me}_{2} \mathrm{SO}_{4}(8 \mathrm{mmol})$ were added dropwise at $0{ }^{\circ} \mathrm{C}$, the temperature was raised to ambient and the stirring was continued for $12 \mathrm{~h}$. The reaction mixture was worked up with $7-10 \%$ aq. $\mathrm{HCl}$, the reaction products were extracted with diethyl ether, dried with $\mathrm{MgSO}_{4}$ and isolated by distillation in vacuo.

4,4-Dimethylspiro[2.7]decane (36a). B.p. 96-98 ${ }^{\circ} \mathrm{C}$ (1 Torr.). IR (film) $v$ 770, 1050, 1395, 1430, 1498, 2910, 3050, $3070 \mathrm{~cm}^{-1}$; ${ }^{1} \mathrm{H}$ NMR $\left(\mathrm{CDCl}_{3}, 400 \mathrm{MHz}\right) \delta 1.51-1.55$ (м, 4H), 1.34-1.43 $(\mathrm{m}, 16 \mathrm{H}), 0.75(\mathrm{~s}, 6 \mathrm{H}), 0.31-0.33(\mathrm{~m}, 2 \mathrm{H}), 0.23-0.24(\mathrm{~m}, 2 \mathrm{H}) ;{ }^{13} \mathrm{C} \mathrm{NMR}\left(\mathrm{CDCl}_{3}, 100 \mathrm{MHz}\right) \delta$ 38.6, 35.2, 32.2, 30.1, 27.4, 25.5, 24.8, 24.4, 24.1, 23.1, 22.7, 20.9, 19.8, 5.4; MS (ES) m/z [M] ${ }^{+}$ 222. Anal. Calcd. for $\mathrm{C}_{16} \mathrm{H}_{30}$ : C, 86.40; H, 13.60. Found: C, 86.29; H, 13.57 .

Synthesis of 4-methylenespiro[2.7]decane $37 \mathrm{a}$ and dimethylenespirooctadecanes 41a,b. General procedure

Cyclic alkyne (10 mmol) or diyne (5 mmol), $\mathrm{Cp}_{2} \mathrm{ZrCl}_{2}(1 \mathrm{mmol})$, hexane $(20 \mathrm{~mL})$, and $\mathrm{Et}_{3} \mathrm{Al}(30$ mmol) were placed into a glass reactor under dry argon at $0{ }^{\circ} \mathrm{C}$ with stirring. The temperature was elevated to ambient $\left(20-21{ }^{\circ} \mathrm{C}\right)$ and the reaction mixture was stirred for $6 \mathrm{~h}$, then, $\mathrm{BrCH}_{2} \mathrm{OCH}_{3}(10 \mathrm{mmol})$ were added dropwise at $-78{ }^{\circ} \mathrm{C}$, the temperature was raised to ambient and the stirring was continued for $12 \mathrm{~h}$. The reaction mixture was worked up with 7-10\% aq. $\mathrm{HCl}$, the reaction products were extracted with diethyl ether, dried with $\mathrm{Na}_{2} \mathrm{CO}_{3}$ and isolated by column chromatography $\left(\mathrm{SiO}_{2}\right.$, hexane-benzene, 10:1).

4-Methylenespiro[2.7]decane (37a). Rf 0.67. IR (film) v 725, 895, 1055, 1460, 1640, 2859, 2920, $2995 \mathrm{~cm}^{-1} ;{ }^{1} \mathrm{H} \mathrm{NMR}\left(\mathrm{CDCl}_{3}, 400 \mathrm{MHz}\right) \delta 4.73(\mathrm{~m}, 2 \mathrm{H}), 2.13(\mathrm{t}, J=8 \mathrm{~Hz}, 2 \mathrm{H}), 1.56-1.58$ $(\mathrm{M}, 2 \mathrm{H}), 1.32-1.44(\mathrm{~m}, 16 \mathrm{H}), 0.53-0.61(\mathrm{~m}, 4 \mathrm{H}) ;{ }^{13} \mathrm{C} \mathrm{NMR}\left(\mathrm{CDCl}_{3}, 100 \mathrm{MHz}\right) \delta 151.2,107.4$, 35.2 , 32.2, 30.2, 29.4, 26.1, 25.4 24.5, 24.3, 24.0, 23.5, 23.1, 12.2; MS (ES) m/z [M] $]^{+} 206$. Anal. Calcd. for $\mathrm{C}_{15} \mathrm{H}_{26}$ : C, 87.30; H, 12.70. Found: C, 87.09; H, 12.72.

12,18-Dimethylenedispiro[2.5.2.7]octadecane (41a). Rf 0.56. IR (film) v 720, 895, 1048, 1461, 1640, 2859, 2928, $2999 \mathrm{~cm}^{-1} ;{ }^{1} \mathrm{H} \mathrm{NMR}\left(\mathrm{CDCl}_{3}, 400 \mathrm{MHz}\right) \delta 4.76(\mathrm{~m}, 4 \mathrm{H}), 2.06(\mathrm{t}, \mathrm{J}=8 \mathrm{~Hz}$, $4 \mathrm{H}), 1.56-1.64(\mathrm{~m}, 4 \mathrm{H}), 1.38-1.55(\mathrm{~m}, 8 \mathrm{H}), 1.30(\mathrm{~m}, 4 \mathrm{H}), 0.56-0.61(\mathrm{~m}, 8 \mathrm{H}) ;{ }^{13} \mathrm{C} \mathrm{NMR}\left(\mathrm{CDCl}_{3}\right.$, $100 \mathrm{MHz}) \delta 151.6,107.8,35.1,29.5,27.4,26.2,26.0,25.3,23.4,12.0 ;$ MS (ES) m/z [M] 272. Anal. Calcd. for $\mathrm{C}_{20} \mathrm{H}_{32}$ : C, 88.16; H, 11.84. Found: C, 87.96; H, 11.82.

4,13-Dimethylenedispiro[2.6.2.6]octadecane (41b). 0.49. IR (film) $v$ 720, 890, 1047, 1464, $1640\left(\mathrm{C}=\mathrm{CH}_{2}\right), 2855,2928,2990 \mathrm{~cm}^{-1} ;{ }^{1} \mathrm{H} \mathrm{NMR}\left(\mathrm{CDCl}_{3}, 400 \mathrm{MHz}\right) \delta 4.76(\mathrm{~m}, 4 \mathrm{H}), 2.11(\mathrm{t}, J=$ $8 \mathrm{~Hz}, 4 \mathrm{H}), 1.56-1.64(\mathrm{~m}, 4 \mathrm{H}), 1.31-1.35(\mathrm{~m}, 8 \mathrm{H}), 1.30(\mathrm{~m}, 4 \mathrm{H}), 0.34(\mathrm{~m}, 8 \mathrm{H}) ;{ }^{13} \mathrm{C} \mathrm{NMR}\left(\mathrm{CDCl}_{3}\right.$, $100 \mathrm{MHz}) \delta 151.8,109.1,35.5,31.2,26.9,26.4,23.8,23.5,12.2$; MS (ES) $\mathrm{m} / \mathrm{z}[\mathrm{M}]^{+} 272$. Anal. Calcd. for $\mathrm{C}_{20} \mathrm{H}_{32}$ : C, 88.16; H, 11.84. Found: C, 88.01; H, 11.83 .

\section{Synthesis of dispiro[2.0.2.6]dodecane (38a) and tetraspiro $\left[2.0 .2^{4} \cdot 5.2^{12} \cdot 0.2^{15} \cdot 5^{3}\right]$ docosane (42)} General procedure

4-Methylenespiro[2.7]decane 37a $(2 \mathrm{mmol})$ or mixture dimethylenespirooctadecanes 41a,b (1 $\mathrm{mmol})$, dichloromethane $(10 \mathrm{~mL})$, diiodomethane $(2.2 \mathrm{mmol})$ and $\mathrm{Et}_{3} \mathrm{Al}(2.2 \mathrm{mmol})$ were placed into a glass reactor under dry argon at $0{ }^{\circ} \mathrm{C}$ with stirring. The temperature was elevated to 
ambient $\left(20-21^{\circ} \mathrm{C}\right)$ and the reaction mixture was stirred for $6 \mathrm{~h}$. The reaction mixture was worked up with $7-10 \%$ aq. $\mathrm{HCl}$, the reaction products were extracted with diethyl ether, dried with $\mathrm{Na}_{2} \mathrm{CO}_{3}$ and isolated by column chromatography $\left(\mathrm{SiO}_{2}\right.$, pentane).

Dispiro[2.0.2.6]dodecane (38a). $\mathrm{Rf}=0.41$. IR (film) $v$ 730, 762, 1025, 1185, 1454, 2860, 2925, 2997, $3074 \mathrm{~cm}^{-1}$; ${ }^{1} \mathrm{H}$ NMR $\left(\mathrm{CDCl}_{3}, 400 \mathrm{MHz}\right) \delta 1.55-1.64(\mathrm{~m}, 4 \mathrm{H}), 1.27-1.47(\mathrm{~m}, 16 \mathrm{H}), 0.53-$ $0.62(\mathrm{~m}, 8 \mathrm{H}) ;{ }^{13} \mathrm{C} \mathrm{NMR}\left(\mathrm{CDCl}_{3}, 100 \mathrm{MHz}\right) \delta 34.7,29.7,27.9,22.6,20.4,9.5 ; \mathrm{MS}(\mathrm{ES}) \mathrm{m} / \mathrm{z}[\mathrm{M}]^{+}$ 220. Anal. Calcd. for $\mathrm{C}_{16} \mathrm{H}_{28}$ : C, 87.19; H, 12.81. Found: C, 87.05; H, 12.80 .

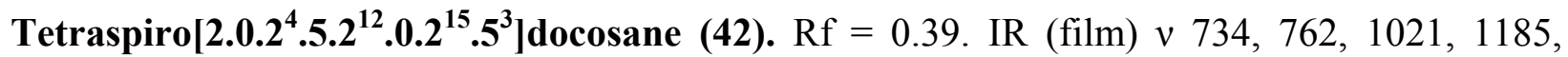
1458, 2860, 2929, 2999, $3070 \mathrm{~cm}^{-1}$; ${ }^{1} \mathrm{H}$ NMR $\left(\mathrm{CDCl}_{3}, 400 \mathrm{MHz}\right) \delta 1.59(\mathrm{~m}, 8 \mathrm{H}), 1.29-1.46(\mathrm{~m}$, 12H), 0.60-0.63 (m, 16H); ${ }^{13} \mathrm{C} \mathrm{NMR}\left(\mathrm{CDCl}_{3}, 100 \mathrm{MHz}\right) \delta 9.3,20.6,22.4,27.3,35.3$; MS (ES) $\mathrm{m} / \mathrm{z}[\mathrm{M}]^{+}$300. Anal. Calcd. for $\mathrm{C}_{22} \mathrm{H}_{36}$ : C, 87.93; H, 12.07. Found: C, 87.74; H, 12.05 .

\section{Acknowledgements}

The work was financially supported by the Russian Foundation for Basic Research (Grant No. 10-03-00046) and by FTP «Scientific and scientific-pedagogical personnel of innovative Russia» in 2009-2013 (Contract № 02.740.11.0631).

\section{References}

1. (a) Lukin, K. A.; Zefirov, N. S. In The Chemistry of the Cyclopropyl Group; Rappoport, Z. Ed.; Wiley: New York, 1995; Vol. 2, p 861. (b) Rappoport, Z.; Liebman, J. F. The Chemistry of the Cyclobutanes; Wiley: New York, 2005; p 1228. (c) Sambasivarao, K.; Ashoke, C. D.; Kakali, L.; Ethirajan, M. Synthesis 2009, 165.

2. (a) Ramazanov, I.R.; Dil'mukhametova, L. K.; Khalilov, L. M.; Dzhemilev, U. M.; Nefedov, O. M. Tetrahedron Lett. 2008, 49, 6058. (b) Ramazanov, I. R.; Yumagulova, A. V.; Dzhemilev U. M.; Nefedov O. M. Tetrahedron Lett. 2009, 50, 4233.

3. Kulinkovich, O. G. Chem. Rev. 2003, 103, 2597.

4. Dzhemilev, U. M.; Khafizova, L.O.; Gubaidullin, R. R.; Khalilov, L. M.; Ibragimov, A. G. Tetrahedron Lett. 2009, 50, 7086.

5. (a) Dzhemilev, U. M.; Ibragimov, A. G.; Zolotarev, A. P.; Muslukhov, R. R.; Tolstikov, G. A. Izv. Akad. Nauk SSSR, Ser. Khim. 1989, 207; Bull. Acad. Sci. USSR, Div. Chem. Sci. 1989, 38, 194. (b) Dzhemilev, U. M.; Ibragimov, A. G.; Vostrikova, O. S.; Tolstikov, G. A. Izv. Akad. Nauk SSSR, Ser. Khim. 1985, 207. Bull. Akad. Sci. USSR, Div. Chem. Sci. 1985, 34, 196. (c) Kondakov. D. Y.; Negishi, E. J. Am. Chem. Soc. 1996, 118, 1577. (d) Dawson, G.; Durrant, C. A.; Kirk, G. G.; Whitby, R. J.; Jones, R. V. H.; Standen, M. C. H. Tetrahedron Lett. 1997, 38, 2335. (e) Millward, D. B.; Cole, A. P.; Waymouth, R. M. Organometalics 2000, 19, 1870. (f) D’yakonov, V. A.; Timerkhanov, R. K.; Ibragimov, A. G.; Dzhemilev, U. 
M. Izv. Akad. Nauk, Ser. Khim. 2007, 2156; Russ.Chem. Bull., Int. Ed. 2007, 56, 2232. (g) D’yakonov, V. A.; Timerkhanov, R. K.; Tuymkina, T. V.; Popod'ko, N. R.; Ibragimov, A. G.; Dzhemilev, U. M. Tetrahedron Lett. 2009, 50, 1270.

6. (a) In Vazhneishie Resul'taty v Oblasti Estestvennykh i Obshchestvennykh Nauk za 1990 god (Otchet Akad. Nauk SSSR), Moskva, 1991 (Major Results in the Field of Natural and Social Sciences for 1990 (Report of Academy of Sciences of the USSR), Moscow, 1991). (b) Dzhemilev, U. M.; Ibragimov, A. G.; Zolotarev, A. P. Mendeleev Commun. 1992, 135. (c) Dzhemilev, U. M.; Ibragimov, A. G.; Ramazanov, I. R.; Luk’yanova, M. P.; Sharipova, A. Z. Izv. Akad. Nauk, Ser. Khim. 2001, 465; Russ. Chem. Bull., Int. Ed. 2001, 50, 484. (d) Negishi, E.; Montchamp, J.-L.; Anastasia, L.; Elizarov, A.; Choueiry, D. Tetrahedron Lett. 1998, 39, 2503. (e) D’yakonov, V. A.; Timerkhanov, R. K.; Tuymkina, T. V.; Dzhemilev, U. M. Izv. Akad. Nauk. Ser. Khim. 2009, 2378; Russ.Chem. Bull., Int. Ed. 2009, 58.

7. (a) Dzhemilev, U. M.; Sultanov, P. M.; Gaimaldinov, R. G.; Muslukhov, R. R. In Materialy Vsesoyuznoi Konferentsii Primenenie metallokompleksnogo kataliza $v$ organicheskom sinteze, Tez. Dokl., Ufa 1989, 40; Proceedings of the All-Union Conference Application of Metallocomplex Catalysis to Organic Synthesis, Abstracts of Reports, Ufa, 1989. (b) Dzhemilev, U. M., Sultanov, P. M.; Gaimaldinov, R. G.; Tolstikov, G. A. Izv. Akad. Nauk SSSR, Ser. Khim. 1991, 1388; Bull. Acad. Nauk USSR, Div. Chem. Sci. 1991, 40, 1229. (c) Dzhemilev, U. M.; Sultanov, R. M.; Gaimaldinov, R. G. J. Organomet. Chem. 1995, 491, 1. (d) Lewis, D. P.; Muller, P. M.; Whitby, R. J.; Jones, R. V. Tetrahedron Lett. 1991, 32, 6797.

(e) Knight, K. S.; Wang, D.; Waymouth, R. M. J. Am. Chem. Soc. 1994, 116, 1845. (f) Dzhemilev, U. M.; D’yakonov, V. A.; Khafizova, L. O.; Ibragimov, A. G. Tetrahedron 2004, 60, 1287. (g) D’yakonov, V. A.; Makarov, A. A.; Ibragimov, A. G.; Dzhemilev, U. M. Zhurn. Organ. Khimii 2008, 44, 207; Russ. J. Org. Chem. 2008, 44, 197.

8. (a) Name Reactions and Reagents in Organic Synthesis Mundy, B. P.; Ellerd M. G.; Favaloro, F. G. Jr. Eds. Wiley-Interscience. New Jersey. USA. 2005.882 pp. (b) Dzhemilev, U. M. Tetrahedron 1995, 51, 4333. (c) Dzhemilev, U. M. Mendeleev Commun. 2008, 18, 1. (d) Dzhemilev, U. M.; Ibragimov, A. G. J. Organomet. Chem. 2010, 695, 1085 . (e) D'yakonov, V. A. Dzhemilev Reaction in Organic and Organometallic Synthesis, NewYork.: NOVA Sci. Publ., 2010. p. 96. (f) D’yakonov, V. A. In “Organometallic Compounds: Preparation, Structure and Properties”. Ed. H. F. Chin, New-York : Nova Sci. Publ., 2009, p 425.

9. Dzhemilev, U. M.; Ibragimov, A. G.; Ramazanov, I. R.; Luk’yanova, M. P.; Sharipova, A. Z.; Khalilov, L. M. Izv. Akad. Nauk, Ser. Khim. 2000, 1092; Russ. Chem. Bull. 2000, 49, 1086.

10. Dzhemilev, U. M.; Ibragimov, A. G.; Zolotarev, A. P.; Khalilov, L. M.; Muslukhov, R. R. Izv. Akad. Nauk SSSR, Ser. Khim. 1992, 386; Bull. Russ. Akad. Sci., Div. Chem. Sci. 1992, 41,300 .

11. D’yakonov, V. A.; Finkelshtein, E. Sh.; Ibragimov, A. G. Tetrahedron Lett. 2007, 48, 8583. 
12. D’yakonov, V. A.; Trapeznikova, O. A.; Ibragimov, A. G.; Dzhemilev, U. M. Izv. Akad. Nauk. Ser. Khim. 2009, 926 [Russ.Chem. Bull., Int. Ed. 2009, 58, 948 (Engl. Transl.)].

13. D’yakonov, V. A.; Makarov, A. A.; Ibragimov, A. G.; Khalilov, L. M.; Dzhemilev, U. M. Tetrahedron 2008, 64, 10188.

14. (a) Skattebol, L.; Solomon, S. J. Am. Chem. Soc. 1965, 87, 4506. (b) Moore, W. R.; Bach, R. D.; Ozretich, T. M. J. Am. Chem. Soc. 1969, 91, 5918. (c) Binger, P.; Schuchardt, U. Chem. Ber., 1980, 113, 1063.

15. Mashima, K.; Sakai, N.; Takaya, H. Bull. Chem. Soc. Jpn. 1991, 64, 2475. 